\title{
The introduced Argentine ant (Linepithema humile) on the California Channel Islands: distribution and patterns of spread
}

\author{
Christina L. Boser ${ }^{1}$, Korie Merrill ${ }^{2}$, Robert N. Fisher ${ }^{3}$, Ida Naughton ${ }^{4}$, and David A. Holway,** \\ ${ }^{1}$ The Nature Conservancy, Ventura, CA \\ ${ }^{2}$ Department of Entomology, University of California at Riverside \& Soil Ecology Research Group, \\ San Diego State University, San Diego, CA \\ ${ }^{3}$ Western Ecological Research Center, U.S. Geological Survey, San Diego, CA \\ ${ }^{4}$ Division of Biological Sciences, University of California at San Diego, La Jolla, CA
}

\begin{abstract}
Aвsтract--The Argentine ant (Linepithema humile) is a widespread and abundant introduced species that disrupts ecosystems throughout its introduced range. This invader was inadvertently introduced to Santa Catalina, San Clemente, Santa Cruz, and San Nicolas Islands at various points during the past century but currently appears to be absent from the remaining Channel Islands. Multiple spatially disjunct infestations on each invaded island individually range in size from $<500 \mathrm{~m}^{2}$ to $>427$ ha and encompass a variety of habitats, including large areas that are entirely dominated by native perennial vegetation. The existence of multiple infestations on individual islands suggests that inadvertent introduction by humans serves as an important within-island dispersal mechanism. Multiyear surveys of individual infestations on San Clemente Island and Santa Cruz Island reveal approximately radial patterns of expansion (as a result of colony budding) away from the edge of each infestation. Rates of spread by budding on San Clemente Island range from $10 \mathrm{~m} /$ year to $57 \mathrm{~m} /$ year and are comparable to those on mainland California. Given the documented effects of Argentine ant invasions on Santa Cruz Island, the continued spread of the Argentine ant on the Channel Islands represents a serious environmental concern. Eradication programs underway on San Clemente and Santa Cruz Islands will hopefully result in island-wide elimination of this detrimental invader.
\end{abstract}

RESUMEN.-La hormiga argentina (Linepithema humile) es una especie introducida ampliamente distribuida y abundante, que perjudica a los ecosistemas en todo su rango de introducción. Este invasor fue introducido, inadvertidamente, en varios sitios de las islas Santa Catalina, San Clemente, Santa Cruz y San Nicolás, durante el siglo pasado, aunque actualmente parece estar ausente en el resto de las Islas del Canal. Múltiples infestaciones, separadas espacialmente en cada isla invadida, varían en tamaño (desde $<500 \mathrm{~m}^{2}$ hasta $>427$ hectáreas) y abarcan una variedad de hábitats, incluyendo grandes áreas dominadas completamente por vegetación perenne nativa. La existencia de infestaciones individuales múltiples en islas sugiere que la introducción inadvertida a través de personas sirve como un importante mecanismo de dispersión dentro de la isla. Varios años de estudio de las infestaciones individuales en la Isla San Clemente y en la Isla Santa Cruz revelan patrones de expansión radiales (como resultado de brotes de colonias) fuera del límite de cada infestación. Las tasas anuales de expansión por brotes en la Isla San Clemente varían entre 10-57 m año-1 y son comparables a las de la parte continental de California. Dado los efectos documentados de las invasiones de las hormigas argentinas en la Isla Santa Cruz, la continua propagación de la hormiga argentina en las Islas del Canal representa una seria preocupación ambiental. Se espera que los programas de erradicación en curso en las Islas San Clemente y Santa Cruz den como resultado una amplia eliminación de este invasor perjudicial.

Native to southern South America (Wild 2004), the Argentine ant (Linepithema humile) has become an abundant and disruptive invader in many parts of its introduced range (Holway et al. 2002a). The Argentine ant was first found in California as early as 1905 (Smith 1936) and now widely occurs there, especially along the coast and in the Central
Valley (Ward 1987, Holway 1995, Suarez et al. 1998). Areas invaded by L. humile in California support few native ant species (Tremper 1976, Ward 1987, Human and Gordon 1996, Holway 1998a, 1998b, 2005, Suarez et al. 1998, Mitrovich et al. 2010, Hanna et al. 2015b). Additional impacts of this invasion include reduced prey availability for vertebrate

*Corresponding author: dholway@ucsd.edu 
TABLE 1. Years in which Argentine ant (Linepithema humile) delineation efforts were conducted ("X") by the authors on the 4 Channel Islands known to support this invader. This table does not include earlier surveys conducted by Backlin et al. (2005) on Santa Catalina Island or by Calderwood et al. (1999) on Santa Cruz Island.

\begin{tabular}{|c|c|c|c|c|c|c|c|c|}
\hline Island & 2010 & 2011 & 2012 & 2013 & 2014 & 2015 & 2016 & 2017 \\
\hline Santa Catalina Island & & & & & & $\mathrm{X}$ & $\mathrm{X}$ & \\
\hline San Clemente Island & & $\mathrm{X}$ & & $\mathrm{X}$ & $\mathrm{X}$ & $\mathrm{X}$ & & $\mathrm{X}$ \\
\hline Santa Cruz Island & $\mathrm{X}$ & $\mathrm{X}$ & $\mathrm{X}$ & $\mathrm{X}$ & $\mathrm{X}$ & & & $\mathrm{X}$ \\
\hline San Nicolas Island & $\mathrm{X}$ & & & & $\mathrm{X}$ & $\mathrm{X}$ & $\mathrm{X}$ & $\mathrm{X}$ \\
\hline
\end{tabular}

insectivores, such as horned lizards (Suarez and Case 2002) and shrews (Laakkonen et al. 2001), and the disruption of seed dispersal (Bond and Slingsby 1984) and pollination mutualisms (Hanna et al. 2015b).

In California L. humile achieves dual status as an urban pest and an invader of nonmanaged habitats (Holway et al. 2002a). The Argentine ant is widespread in urban and suburban environments in low-elevation portions of California to the west of the deserts. Within this same region, the Argentine ant invades a variety of nonmanaged habitats but does not persist in areas subject to winter freezing temperatures or in areas that lack sufficient soil moisture (Menke et al. 2007). The view that dry conditions can limit spread in seasonally dry environments is supported by both experimental evidence (Holway et al. 2002b, Menke and Holway 2006, Menke et al. 2007) and observational evidence (Holway and Suarez 2006, Heller et al. 2008). In all invaded areas the inherent dispersal limitations of this species slow the rate of spread away from points of introduction (Suarez et al. 2001). Argentine ant queens do not participate in mating flights, and colony reproduction occurs by budding from established colonies.

Previous studies have described aspects of Argentine ant invasions from Santa Catalina Island (Cockerell 1940, Menke and Miller 1985, Backlin et al. 2005), San Clemente Island (Merrill 2015), and Santa Cruz Island (Calderwood et al. 1999, Wetterer et al. 2000, Hanna et al. 2015a, 2015b), but no single study has attempted to synthesize information concerning the distribution and spread of the Argentine ant across the California Channel Islands as a whole. Here we collate such data-much of which results from recent surveys conducted by the authors of this study - for the 4 Channel Islands where the Argentine ant is established, with the goal of assessing the potential of this invader to expand its range within the archipelago.

\section{Methods}

Years in which we performed delineation surveys on each invaded island are shown in Table 1. To delineate areas invaded by the Argentine ant, we used protocols specifically designed for conditions on Santa Cruz Island (Boser et al. 2017) and San Clemente Island (Merrill et al. 2018). These delineation efforts were implemented for planned or potential Argentine ant eradication programs. Surveys on Santa Catalina Island followed a different protocol that we describe below. During the same time period of the present study (2010-2016), we also carried out surveys on Anacapa, Santa Barbara, San Miguel, and Santa Rosa Islands and did not detect the Argentine ant on these islands despite focused searches in areas thought most likely to support this species.

From within each known infestation, we located and mapped the invasion perimeter as follows. We first travelled away from the presumed center of each infestation until we located native ants known to not co-occur with the Argentine ant on the Channel Islands (Hanna et al. 2015b). Once we located the edge of an infestation, we determined its perimeter by mapping the area of contact between the Argentine ant and native ants until the entire boundary of the infestation was determined (Holway 1998b). Perennial vegetation (both native and introduced, especially Atriplex semibaccata, Baccharis pilularis, Calystegia macrostegia, Foeniculum vulgare, Opuntia littoralis, and Quercus pacifica) proved to be an invaluable aid in delineation because of its attractiveness to ants in general. We collected GPS coordinates at regularly spaced points along each perimeter at intervals usually not exceeding $50 \mathrm{~m}$. For areas with low ant densities (e.g., areas with introduced grasses or otherwise sparse vegetation), we used baits (cotton balls soaked in sucrose water and left in the field for $\sim 60 \mathrm{~min}$ ) to determine what ant species were present. In addition to mapping 
previously known infestations in this manner, we checked man-made structures (both active and inactive), roadsides, areas of human activity, and permanent water sources. New infestations were mapped by implementing the methods described above.

We present known distributional data either from the past several years (e.g., San Nicolas Island) or from prior to the recent implementation of large-scale eradication programs (e.g., for Santa Cruz and San Clemente Islands). For Santa Catalina Island we report Argentine ant presence/absence data for 20 points sampled between 2002 and 2004 by Backlin et al. (2005) and an additional 9 points that were sampled in 2015 and 2016 by D.A. Holway. To investigate temporal patterns of invasion, we summarize multiyear survey data for individual Argentine ant infestations on Santa Cruz and San Clemente Islands. Estimated annual rates of spread were calculated for Wilson Cove at San Clemente Island by measuring perpendicular distances between annual delimitations. The origin points for these estimates were 7 locations along the edge of the original 2011 delimitation; these points were spaced $500 \mathrm{~m}$ apart along the perimeter of this infestation (Merrill 2015; Merrill unpublished data). For each year we report the mean rate of spread estimated across the 7 origin points. The authors of the present study collected all of the distributional data reported here. We do not use maps from Santa Cruz Island published in Calderwood et al. (1999) because those authors did not attempt to map infestation perimeters. We also could not locate earlier unpublished Argentine ant surveys conducted in the 1990s on Santa Catalina and San Nicolas Islands.

\section{RESUlTS}

Delineation surveys revealed qualitatively similar patterns of invasion on San Clemente, San Nicolas, and Santa Cruz Islands (Figs. 1-3). On all 3 islands we detected multiple spatially disjunct infestations that individually varied in size from $<500 \mathrm{~m}^{2}$ to $>427$ ha (Figs. 1-3). The total percentage of invaded area on these islands is $2 \%$ on Santa Cruz Island, $3 \%$ on San Clemente Island, and $13 \%$ on San Nicolas Island. Although almost all of these individual infestations encompass areas modified by humans (e.g., structures or roads), all of the larger infestations, without exception, extend into nonmanaged habitats numerically dominated by native perennial plants. Moreover, the Argentine ant is absent from many humanmodified sites (e.g., roadsides, areas of soil disturbance, buildings) on each island. Infestations on Santa Catalina Island were not mapped in their entirety, but sampling points distributed across the island nonetheless suggest a widespread distribution with points of Argentine ant presence throughout much of the island and with infestations present in all major watersheds and in a variety of habitat types (Fig. 4).

Delineation surveys conducted at individual infestations over multiple years on Santa Cruz and San Clemente Islands revealed approximately radial expansion over time, with no consistent indication that the Argentine ant advanced more quickly into some habitats than others (Fig. 5). For the Wilson Cove infestation on San Clemente Island (Fig. 5B), annual rates of spread ranged from approximately $10 \mathrm{~m} /$ year (2015-2016) to $57 \mathrm{~m} /$ year (2013-2014).

\section{Discussion}

Surveys conducted on the Channel Islands over the past 8 years (Table 1) have revealed that the Argentine ant has collectively invaded over a thousand hectares on San Clemente, Santa Cruz, and San Nicolas Islands (Figs. 1-3) and that individual infestations on San Clemente Island can expand by as much as 57 m/year (Fig. 5). Although exact area estimates are unavailable for Santa Catalina Island where the Argentine ant has been present for a long time (Cockerell 1940), large portions of this island now appear to be invaded (Fig. 4). Based on the distributions shown in Figs. 1-4, uninvaded islands within this archipelago as well as uninvaded portions of presently invaded islands all seem vulnerable to invasion by the Argentine ant.

Individual infestations vary greatly in size on the 3 invaded islands for which we have completely delineated the extent of Argentine ant invasion (Figs. 1-3). Although the age of each infestation is unknown, an approximate chronology of invasion history from Santa Cruz Island strongly suggests that the size of individual infestations is related to age and that multiple infestations are the result of 


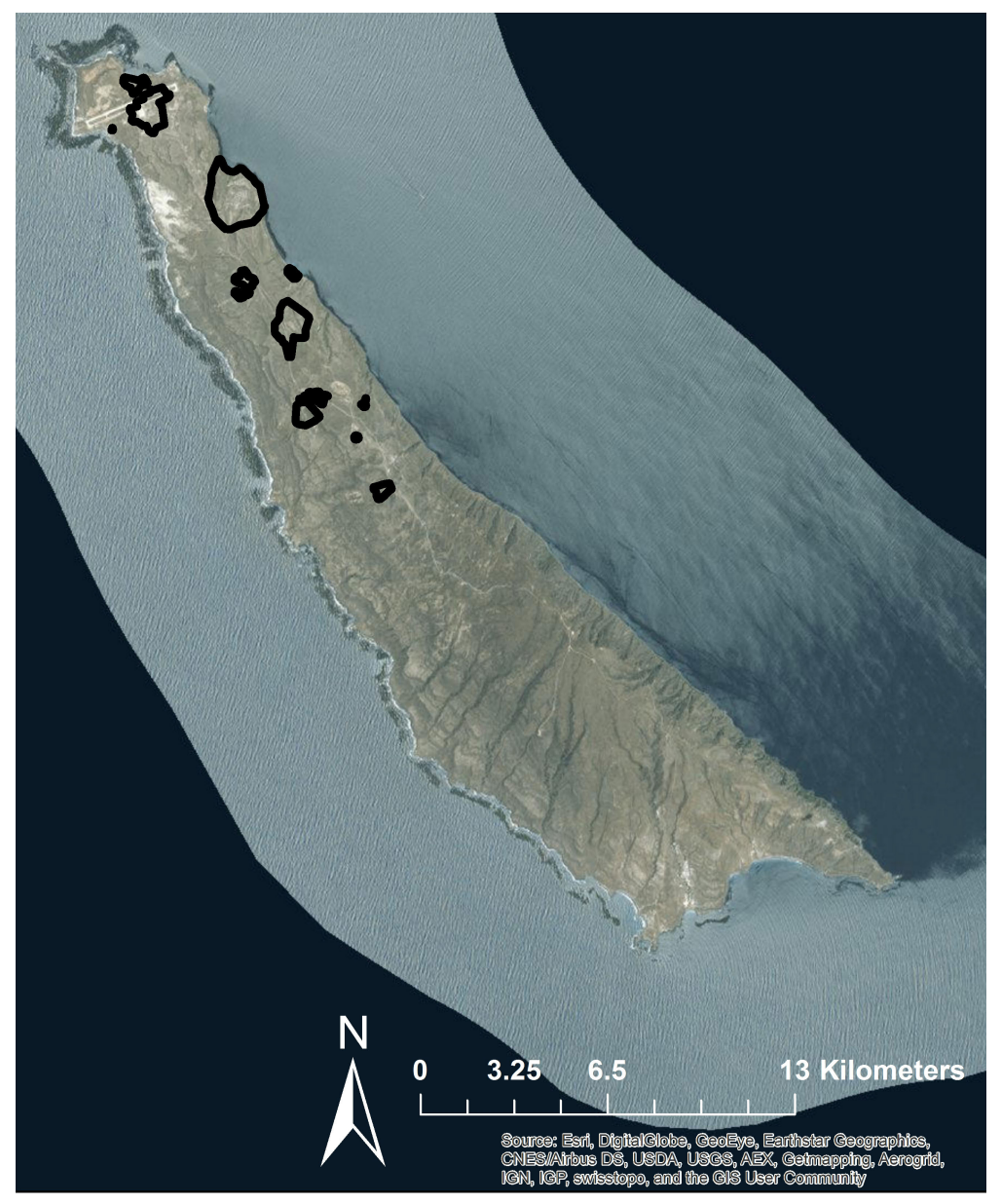

Fig. 1. Island-wide distribution of the Argentine ant (Linepithema humile) on San Clemente Island in 2015. The locations of 11 separate infestations are indicated by polygons outlined in black. The ongoing eradication program on San Clemente Island has greatly reduced the area of infestation depicted in this figure.

accidental within-island introduction by people as opposed to independent introductions from the mainland (Boser et al. 2017). The largest infestation on Santa Cruz Island (Fig. 3), for example, also appears to be the oldest on that island, likely dating back several decades to a now-dismantled U.S. Navy facility on the coastline at Valley Anchorage. Argentine ants were accidentally transported from this infestation to the navy site in the mid-1980s and to the UC Field Station in 1995 via human transport of building material. The infestation in Canada del Puerto seems to be the result of more recent downstream dispersal from the UC Field Station infestation by winter flooding events (Fig. 3). We lack a similar chronology for San Clemente Island and San Nicolas
Island, but the largest infestations on each of these islands are centered around areas of human activity and are thus likely to represent the initial sites of introduction.

Multiyear survey data from Santa Cruz and San Clemente Islands reveal gradual and approximately radial expansion of individual Argentine ant infestations over time (Fig. 5), with estimated rates of spread roughly in line with those measured elsewhere (Holway 1998b, Suarez et al. 2001, Krushelnycky et al. 2005). Limits to invasion associated with dry conditions on the mainland appear to apply less strictly on the Channel Islands where the relatively cool and foggy maritime climate seems conducive to infestation spread. Drought conditions between 2014 and 2016 


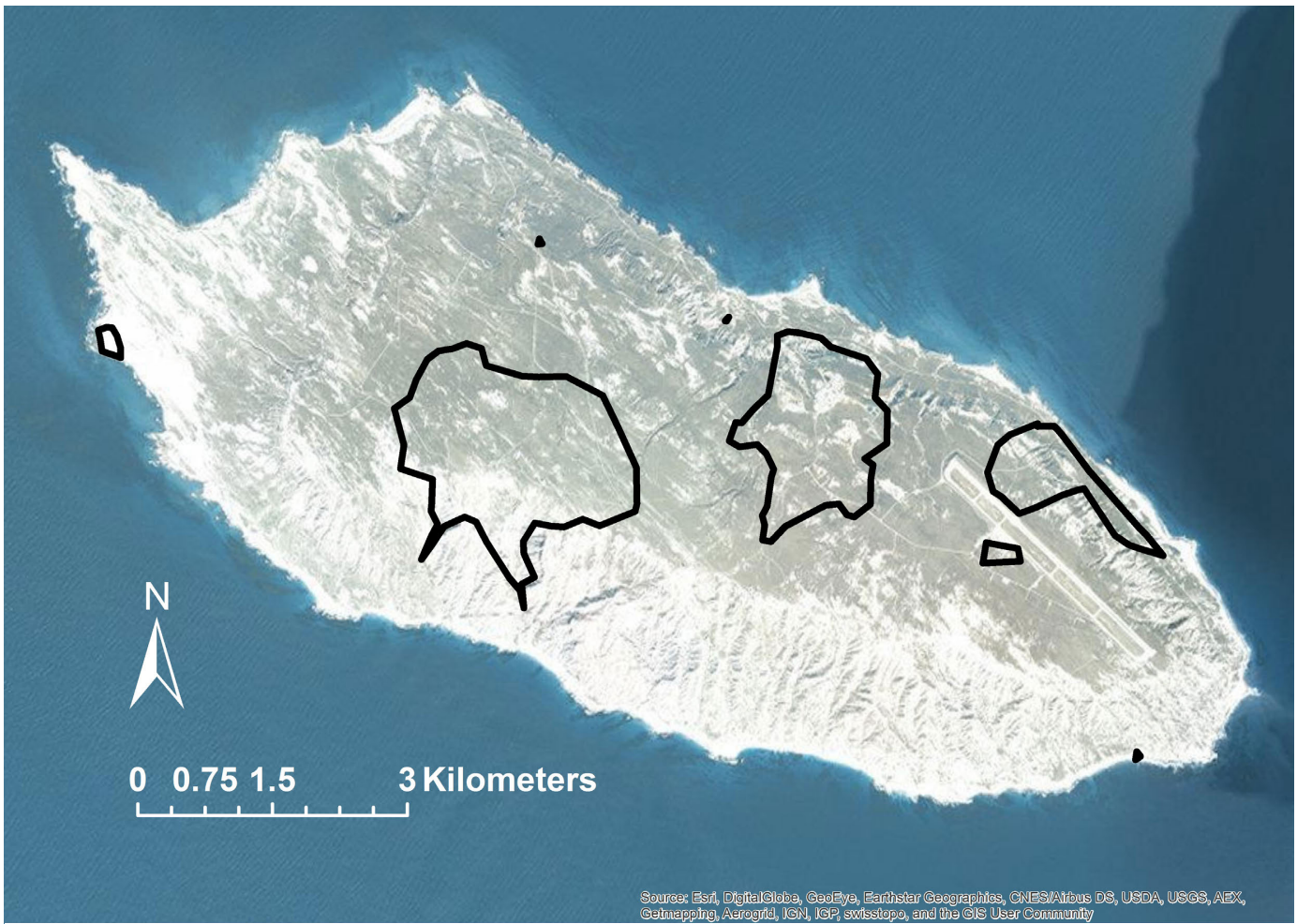

Fig. 2. Island-wide distribution of the Argentine ant (Linepithema humile) on San Nicolas Island in 2016. The locations of 8 separate infestations are indicated by polygons outlined in black.

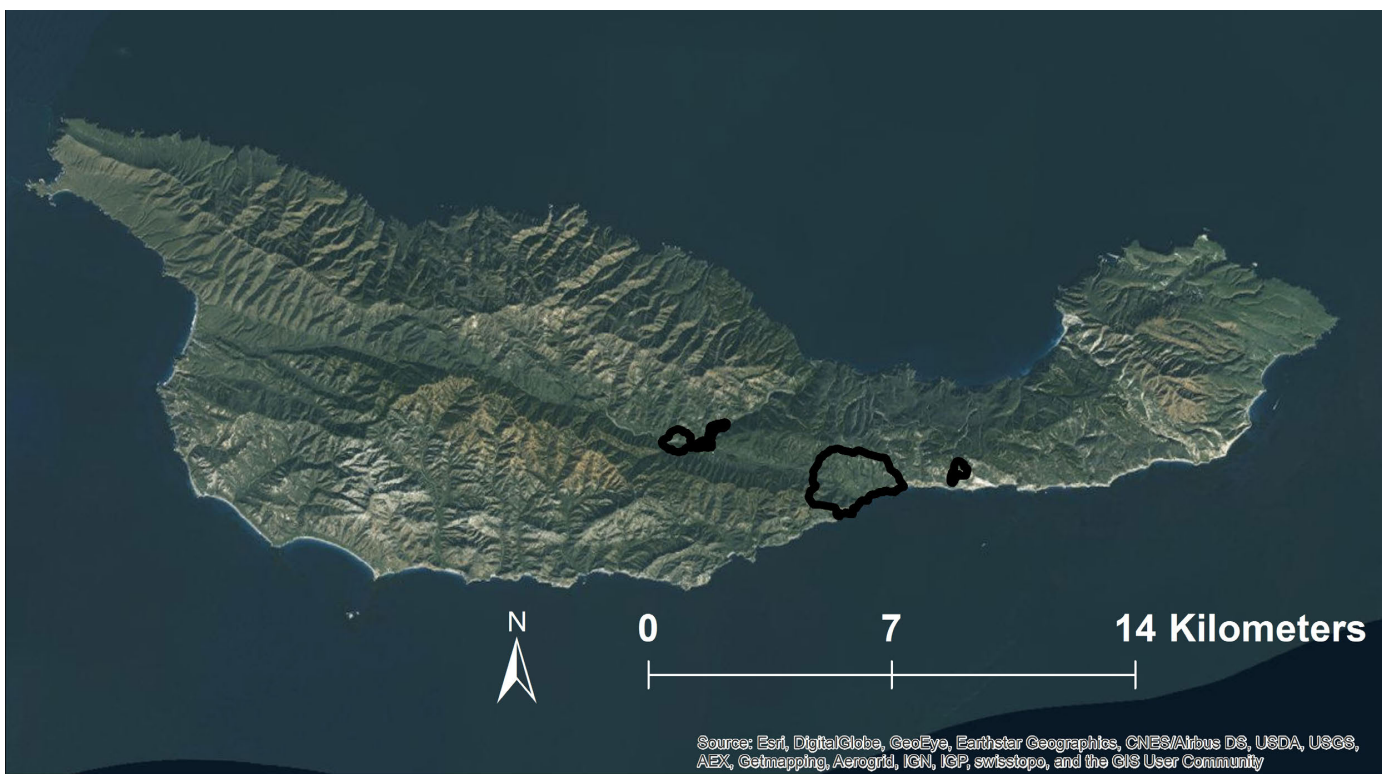

Fig. 3. Island-wide distribution of the Argentine ant (Linepithema humile) on Santa Cruz Island in 2012. The locations of 4 separate infestations are indicated by polygons outlined in black. The ongoing eradication program on Santa Cruz Island has greatly reduced the area of infestation depicted in this figure. 


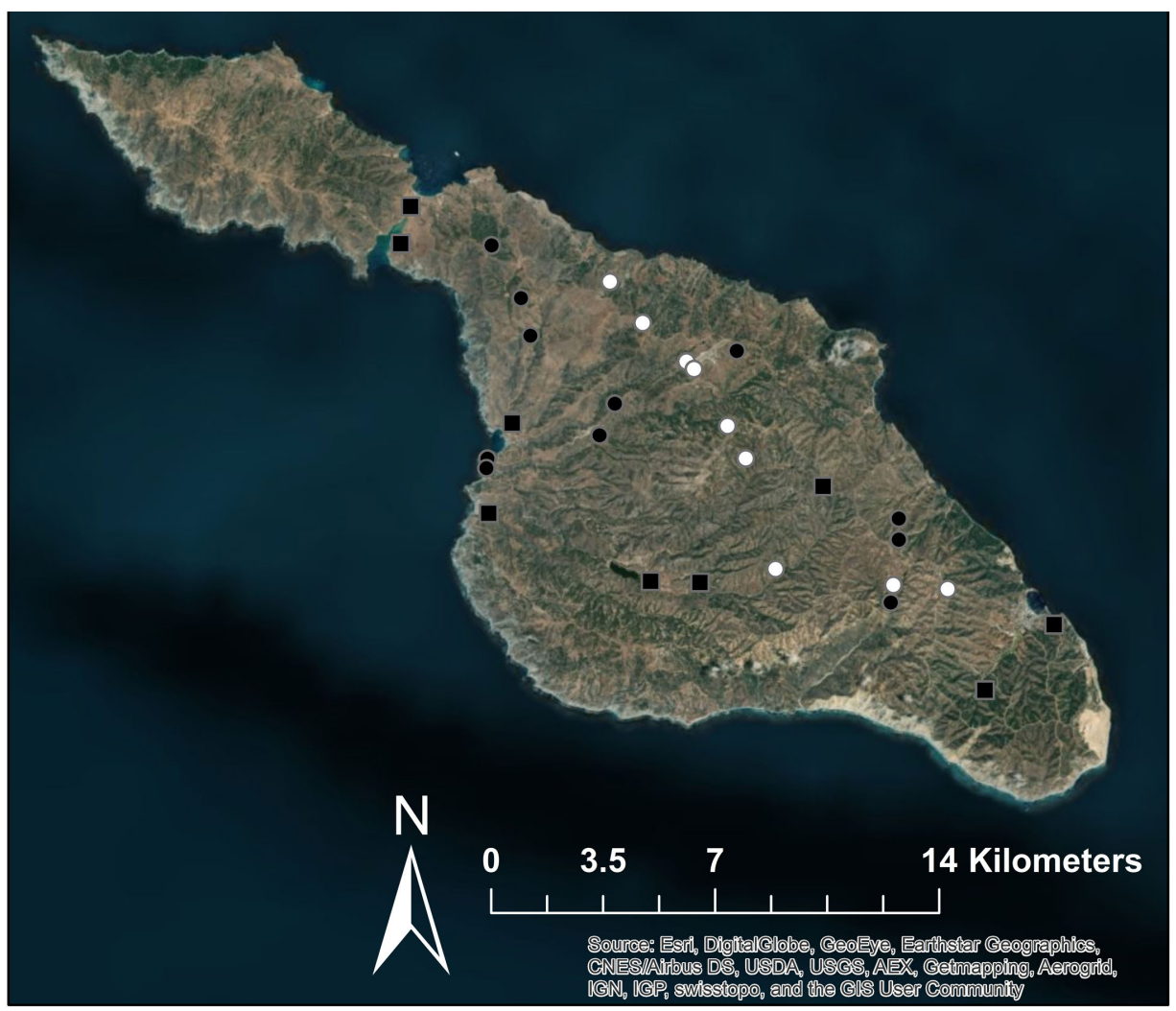

Fig. 4. Argentine ant (Linepithema humile) presence (black circles) or absence (white circles) at 20 points on Santa Catalina Island sampled between 2002 and 2004 (Backlin et al. 2005). Black squares indicate Argentine ant presence at an additional 9 points sampled by D.A. Holway in 2015 and 2016.

may have nonetheless reduced the rate of Argentine ant spread on San Clemente Island. Estimated rates of spread from this island (Fig. 5B), for example, appeared lower between 2014 and 2016 (relatively dry winters) than between 2011 and 2013 (winters with near average rainfall) (see also Heller et al. 2008).

Continued expansion of the Argentine ant on the Channel Islands represents a documented conservation concern. The majority of native ant species present on Santa Cruz Island do not co-occur with the Argentine ant (Hanna et al. 2015b); similar patterns have been observed on the other invaded Channel Islands. The California Channel Islands collectively support over 50 species of native ants, with differentiated and endemic taxa primarily restricted to the southern Channel Islands. The global distribution of Aphaenogaster patruelis, for example, consists of Isla Guadalupe and the 4 southern Channel Islands, including Santa Catalina and San
Nicolas Islands, where populations of this species seem threatened by the Argentine ant. Systematic and phylogeographic studies currently underway could reveal additional ant taxa of conservation concern. The loss of native ant biodiversity resulting from ant invasions represents a widespread problem on islands in the Pacific Ocean (Morrison 2014).

In addition to impacts associated with the loss of native ants, Hanna et al. (2015a) documented that the Argentine ant frequently visits the flowers of native plant species and disrupts pollination services provided by native insects. Experimental removal of the Argentine ant on Santa Cruz Island, for example, increased rates of bee visitation to and decreased levels of pollen limitation in the island morning glory (Calystegia macrostegia) (Hanna et al. 2015a). Given the level of endemism exhibited by the flora of the Channel Islands (Junak et al. 1995), the disruption of pollination mutualisms by the Argentine ant 

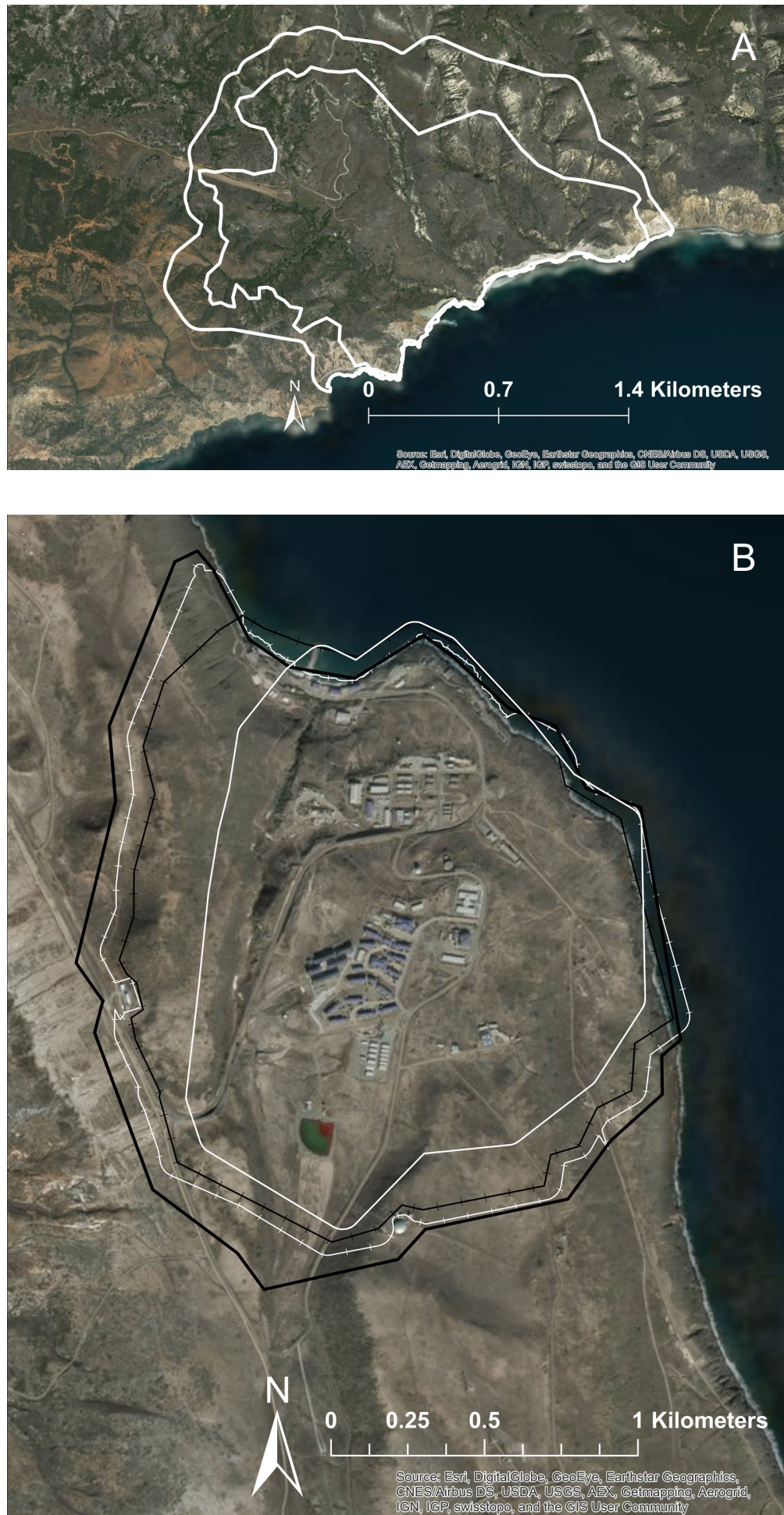

Fig. 5. Patterns of Argentine ant (Linepithema humile) spread over time: A, Valley Anchorage infestation on Santa Cruz Island delineated in 2010 (inner line) and 2015 (outer line); B, Wilson Cove infestation on San Clemente Island delineated in 2011 (innermost line), 2013 (black line with ticks), 2014 (white line with ticks), and 2015 (outermost line). 
represents a subtle but potentially serious effect of these invasions. Other environmentally sensitive or imperiled island flora and fauna may also be negatively affected by continued Argentine ant expansion. Vertebrate insectivores with restricted island distributions, such as the Island Night Lizard (Xantusia riversiana) (Fellers and Drost 1991) and the Santa Catalina Island shrew (Sorex ornatus willetti) (Aarhus 2005), could be impacted by the Argentine ant on the islands where they occur.

Eradication programs underway on San Clemente and Santa Cruz Islands will hopefully result in island-wide elimination of the Argentine ant. Boser et al. (2017) and Merrill et al. (2018) describe eradication methods. Treatments consist of an aqueous solution of sucrose and $6 \mathrm{ppm}$ of thiamethoxam mixed with hydrating polyacrylamide beads. Hydrated beads are distributed either by helicopter or by hand throughout infested areas (and within a 50-m buffer zone) at least 10 times during summer and early fall. Treatment rounds are then repeated a second time, usually in the year following the initial treatment. Ants feed on the solution present on the bead surface for about $24 \mathrm{~h}$; thereafter, the dehydration of beads prevents feeding. This toxicant delivery system effectively transfers thiamethoxam to ants but minimizes its exposure to the soil and to other arthropods (Boser et al. 2017).

Although eradication programs on San Clemente and Santa Cruz Islands are ongoing, treatments have been highly successful at reducing the area invaded by the Argentine ant. On Santa Cruz Island where large-scale treatments ended in 2016, there is currently only one known infestation, which is localized (Boser et al. 2017). Treatments are continuing on San Clemente Island, and the area of Argentine ant infestation has decreased more than $95 \%$ since treatments began on that island in 2013 (Merrill et al. 2018). Ongoing monitoring on both islands involves the use of detection dogs to locate potential areas where the Argentine ant has persisted in treated areas. Spot infestations that are located in the future will be delineated and treated by field crews. Long-term studies are underway to quantify the recovery of native ant assemblages on both San Clemente and Santa Cruz Islands.

\section{ACKNOWLEDGMENTS}

Access to field sites was provided by the Catalina Island Conservancy, the National Park Service, The Nature Conservancy, and the U.S. Navy. For logistical help in the field, we would like to thank Armando Aispuro, Adam Backlin, Jen Baker, Melissa Booker, Stephanie Calloway, Amanda Chisholm, Stephanie Coronado, James Dickinson, Preston Duncan, Calypso Gagorik, Cause Hanna, Aaron Hebshi, Bill Hoyer, John Knapp, Lyndal Laughrin, Tritia Matsuda, John Randall, C. Sheena Sidhu, Makayla Syas, Steven Thielking, and Victor Zhang. Funding was provided by The Nature Conservancy, the National Geographic Society, the U.S. Navy, the National Park Service, the California Wildlife Conservation Board, the California Coastal Conservancy, and the National Science Foundation. Any use of trade, product, or firm names is for descriptive purposes only and does not imply endorsement by the U.S. government.

\section{Literature Cited}

Aarhus, A.J. 2005. Abundance and distribution of the Santa Catalina Island shrew (Sorex ornatus willetti) on Santa Catalina Island, California. Proceedings of the Sixth California Islands Symposium 2005: 249-255.

Backlin, A.R., S.L. Compton, Z.B. Kahancza, and R.N. FISHER. 2005. Baseline biodiversity survey for Santa Catalina Island: herpetofauna and ants with remarks on small mammals and others. United States Geological Survey, Sacramento, CA.

Bond, W., And P. Slingsby. 1984. Collapse of an antplant mutualism: the Argentine ant (Iridomyrmex humilis) and myrmecochorous Proteaceae. Ecology 65:1031-1037.

Boser, C.L., C. Hanna, D.A. Holway, K.R. Faulkner, I. Naughton, K. Merrill, J.M. Randall, C. Cory, AND S.A. MorRison. 2017. Protocols for Argentine ant eradication in conservation areas. Journal of Applied Entomology 141:540-550.

Calderwood, A., A. Wenner, and J.K. Wetterer. 1999. Argentine ants (Hymenoptera: Formicidae) invade California’s Santa Cruz Island. In: D.R. Browne, K.L. Mitchell, and H.W. Cheney, editors, Proceedings of the Fifth California Islands Symposium. U.S. Department of the Interior, Mineral Management Service.

Cockerell, T.D.A. 1940. The insects of the Californian islands. Proceedings of the Sixth Pacific Scientific Congress 4:283-295.

Fellers, G.M., AND C.A. Drost. 1991. Xantusia riversiana. Catalogue of American amphibians and reptiles 516:1-4.

Hanna, C., I. Naughton, C. Boser, R. Alarcón, K.-L.J. Hung, AND D.A. Holway. 2015a. Floral visitation by the Argentine ant reduces bee visitation and plant seed set. Ecology 96:222-230. 
Hanna, C., I. Naughton, C. Boser, and D.A. Holway. $2015 \mathrm{~b}$. Testing the effects of ant invasions on non-ant arthropods with high-resolution taxonomic data. Ecological Applications 25:1841-1850.

Heller, N.E., N.J. Sanders, J.W. Shors, and D.M. GorDON. 2008. Rainfall facilitates the spread, and time alters the impact, of the invasive Argentine ant Oecologia 155:385-395.

Holway, D.A. 1995. Distribution of the Argentine ant (Linepithema humile) in northern California. Conservation Biology 9:1634-1637.

HoLWAY, D.A. 1998a. Factors governing rate of invasion: a natural experiment using Argentine ants. Oecologia 115:206-212.

HolwaY, D.A. 1998b. Effect of Argentine ant invasions on ground-dwelling arthropods in northern California riparian woodlands. Oecologia 116:252-258.

HoLway, D.A. 2005. Edge effects of an invasive species across a natural ecological boundary. Biological Conservation 121:561-567.

Holway, D.A., L. Lach, A.V. Suarez, N.D. Tsutsui, and T.J. CASE. 2002a. The causes and consequences of ant invasions. Annual Review of Ecology and Systematics 33:181-233.

Holway, D.A., AND A.V. Suarez. 2006. Homogenization of ant communities in Mediterranean California: the effects of urbanization and invasion. Biological Conservation 127:319-326.

Holway, D.A., A.V. Suarez, and T.J. CaSe. 2002b. Role of abiotic factors in governing susceptibility to invasion: a test with Argentine ants. Ecology 83:1610-1619.

Human, K.G., AND D.M. GoRdon. 1996. Exploitation and interference competition between the invasive Argentine ant, Linepithema humile, and native ant species. Oecologia 105:405-412.

Junak, S., T. Ayers, R. Scott, D. Wilken, and D. Young. 1995. A flora of Santa Cruz Island. California Native Plant Society, Sacramento, CA.

Krushelnycky, P.D., S.M. Joe, A.C. Medeiros, C.C. DAEHLER, AND L.L. LOOPE. 2005. The role of abiotic conditions in shaping the long-term patterns of a high-elevation Argentine ant invasion. Diversity and Distributions 11:319-331.

Laakkonen, J., R.N. Fisher, and T.J. Case. 2001. Effect of land cover, habitat fragmentation, and ant colonies on the distribution and abundance of shrews in southern California. Journal of Animal Ecology 70: $776-788$

Menke, A.S., And D.R. Miller, Editors. 1985. Entomology of the California Channel Islands: proceedings of the first symposium. Santa Barbara Museum of Natural History, Santa Barbara, CA

Menke, S.B., R.N. Fisher, W. Jetz, and D.A. Holway 2007. Biotic and abiotic controls of Argentine ant invasion success at local and landscape scales. Ecology 88:3164-3173.

Menke, S.B., and D.A. Holway. 2006. Abiotic factors control invasion by ants at the community scale. Journal of Animal Ecology 75:368-376.
Merrill, K.C. 2015. Management and monitoring of Linepithema humile (Mayr) on San Clemente Island, California. Master's thesis, University of California, Riverside, CA.

Merrill, K.C., C.L. Boser, C. Hanna, D.A. Holway, I. Naughton, D.-H. Choe, and E.E. Wilson Rankin. 2018. Argentine ant (Linepithema humile, Mayr) eradication efforts on San Clemente Island, California, USA. Western North American Naturalist 78: 829-836.

Mitrovich, M.J., T. Matsuda, K.H. Pease, and R.N. Fisher. 2010. Ants as a measure of effectiveness of habitat conservation planning in southern California. Conservation Biology 24:1239-1248.

Morrison, L.W. 2014. The ants of remote Polynesia revisited. Insectes Sociaux 61:217-228

Smith, M.R. 1936. Distribution of the Argentine ant in the United States and suggestions for its control or eradication. United States Department of Agriculture Circular 387:1-39.

Suarez, A.V., D.T. Bolger, and T.J. Case. 1998. Effects of fragmentation and invasion on native ant communities in coastal southern California. Ecology 79: 2041-2056.

Suarez, A.V., AND T.J. CASE. 2002. Bottom-up effects on persistence of a specialist predator: ant invasions and horned lizards. Ecological Applications 12:291-298.

Suarez, A.V., D.A. Holway, and T.J. Case. 2001. Patterns of spread in biological invasions dominated by longdistance jump dispersal: insights from Argentine ants. Proceedings of the National Academy of Sciences 98:1095-1100.

Tremper, B.S. 1976. Distribution of the Argentine ant, Iridomyrmex humilis Mayr, in relation to certain native ants of California: ecological, physiological and behavioural aspects. Doctoral dissertation, University of California, Berkeley, CA

WARD, P.S. 1987. Distribution of the introduced Argentine ant (Iridomyrmex humilis) in natural habitats of the lower Sacramento Valley and its effects on the indigenous ant fauna. Hilgardia 55(2):1-16.

Wetterer, J.K., P.S. Ward, A.L. Wetterer, J.T. Longino, J.C. Trager, and S.E. Miller. 2000. Ants (Hymenoptera: Formicidae) of Santa Cruz Island, California. Bulletin of the Southern California Academy of Sciences 99:25-31.

WILD, A.L. 2004. Taxonomy and distribution of the Argentine ant, Linepithema humile. Annals of the Entomological Society of America 97:1204-1215.

Received 28 February 2017

Revised 20 December 2017

Accepted 12 January 2018

Published online 25 October 2018 